\title{
VALIDATION OF NLFEA OF REINFORCED CONCRETE WALLS UNDER BIDIRECTIONAL LOADING
}

\section{VALIDAZIONE DELLE NLFEA DI PARETI IN CA SOGGETTE A CARICHI BIDIREZIONALI}

\author{
B. Belletti ${ }^{1}$, M. Scolari ${ }^{2}$, J. Almeida ${ }^{3}$, K. Beyer ${ }^{4}$ \\ ${ }^{1}$ DICATeA, University of Parma, Italy, beatrice.belletti@unipr.it \\ ${ }^{2}$ DICATeA, University of Parma, Italy, scolari.matteo87@gmail.com \\ ${ }^{3}$ EESD, École Polytecnique Fédérale de Lausanne (EPFL), joao.almeida@epfl.ch \\ ${ }^{4}$ EESD, École Polytecnique Fédérale de Lausanne (EPFL), katrin.beyer@epfl.ch
}

\begin{abstract}
Nonlinear Finite Element Analysis (NLFEA) of the inelastic behaviour of RC walls are often carried out for uni-directional (in-plane) horizontal cyclic loading. In this paper the behaviour of RC walls with different crosssections (T-shaped and U-shaped) subjected to bi-directional (in-plane and out-of-plane) loading is simulated by means of NLFEA. They are carried out with the software DIANA, using curved shell elements and a total strain crack model for concrete and embedded truss elements adopting Monti-Nuti model for the reinforcement. The aim of this paper is to validate this type of analysis by comparing the obtained results with experimental outcomes of two different RC slender walls, a T-shaped wall and a U-shaped wall, tested under quasi-static bidirectional cyclic load. In particular, the focus is on the comparison between different crack models (Fixed and Rotating crack models) and on the calibration of the Monti-Nuti model parameters for steel. NLFEA is found to acceptably simulate both the in-plane and out-of-plane behaviour observed during the experimental tests. The present work is the starting point for future research in which parametric studies on the influence of reinforcement content and detailing will be performed, assessing their influence on the bidirectional response of RC walls and namely on other less known deformation modes such as out-of-plane instability. / Le analisi non lineari ad elementi finiti (NLFEA) del comportamento inelastico di pareti in calcestruzzo armato sono usualmente condotte considerando carichi orizzontali ciclici unidirezionali (nel piano della parete). Nella presente memoria verrà simulato, per mezzo di NLFEA, il comportamento di pareti in calcestruzzo armato con differente sezione trasversale (sezione a $\mathrm{T}$ e sezione a U) soggette a carichi ciclici bidirezionali (nel piano e fuori dal piano). Le analisi sono state condotte utilizzando il software DIANA, adottando elementi shell curvi. Il comportamento del calcestruzzo è stato simulato per mezzo di un modello fessurativo a deformazioni totali mentre le barre di armatura sono state modellate come "embedded truss" adottando il modello Monti-Nuti per definire il comportamento del materiale acciaio. Lo scopo di questa memoria è quello di validare questa tipologia di analisi comparando i risultati ottenuti con prove sperimentali di due differenti pareti in calcestruzzo armato, una parete con sezione a $\mathrm{T}$ e una parete con sezione a U. In particolare l'attenzione è stata posta sul confronto tra diversi modelli fessurativi (modello fessurativo a fessura fissa o a fessura rotante) e sulla calibrazione dei parametri del modello Monti-Nuti. Le analisi non lineari ad elementi finiti sono state capaci di prevedere sia il comportamento nel piano che quello fuori dal piano delle pareti testate. La presente memoria può infine essere considerata come il punto di partenza per future ricerche atte a valutare l'influenza di differenti dettagli costruttivi e percentuali di armature sulla risposta di pareti in calcestruzzo armato soggette a carichi bidirezionali e in particolare su altre meno note modalità di rottura, come l'instabilità fuori dal piano.
\end{abstract}

KEYWORDS: Reinforced concrete walls, thin walls, out-of-plane instability, nonlinear finite element analysis, cyclic load / pareti in calcestruzzo armato, pareti snelle, instabilità fuori dal piano, analisi non lineari ad elementi finiti, carichi ciclici

\section{INTRODUCTION}

Reinforced concrete (RC) walls are commonly used as the primary lateral force-resisting system for medium to high-rise buildings. Nevertheless, despite many years of research and subsequent evolution of code provisions, several RC walls still underperform when subjected to seismic actions, as demonstrated by the recent earthquakes in Chile (February 2010) and New Zealand (February 2011).

The observation of the damage occurred in these later seismic events (Wallace 2012) highlighted that many walls, in their failed configuration, were char- 
acterized by large out-of-plane displacements. The failure of these structural walls was hence caused or highly influenced by the out-of-plane buckling (also defined as out-of-plane instability), which is triggered in the end region of the wall. It is noted that this deformation mode may be the result of the application of pure in-plane cyclic loading, see Figure 1.

These seeming faults in the design of structural walls are emphasized also by analysing international code provisions. Indeed, the majority of standards treats the out-of-plane instability in a simplified way by imposing limits on the height to thickness ratio of the wall. Only the New Zealand code includes more sophisticated models based on the studies by Goodsir, Paulay and Priestley (Goodsir 1985, Paulay \& Priestley 1993).

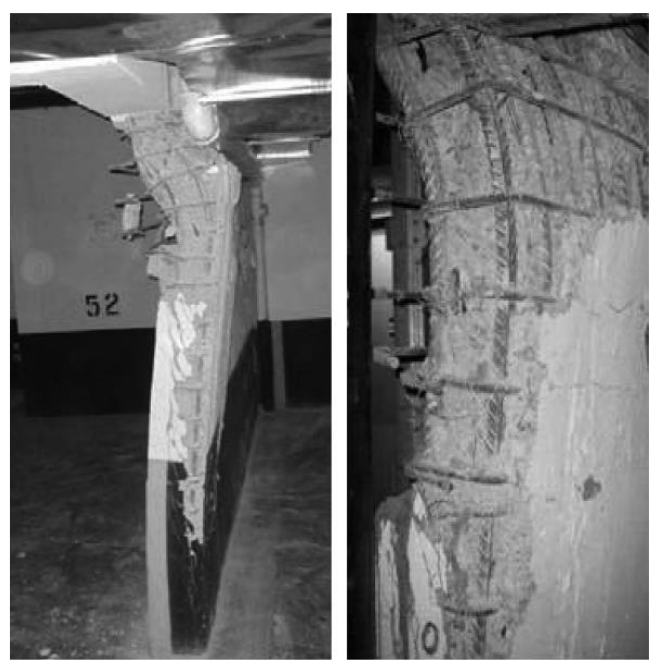

Figure 1 - Out-of-plane buckling of walls after 2010 Chile earthquake / Instabilità fuori dal piano delle pareti in seguito al sisma del 2010 in Cile (Wallace 2012)

Prior to the Chile and New Zealand earthquakes this failure mechanism had only been observed in laboratory tests (Oesterle 1979, Vallenas et al. 1979, Thomsen IV \& Wallace 2004). In the recent years the research on this topic has been continued by joining experimental test campaigns with advanced nonlinear finite element analysis (NLFEA).

NLFEA are a widely validated numerical tool to simulate the behavior of RC walls, both considering pushover (Belletti et al. 2013, Damoni et al. 2014) and cyclic analyses (Belletti et al. 2016a, Belletti et al. 2016b). Recently, this numerical tool was also applied to the study of out-of-plane instability. In particular, Dashti et al. (2014) and Dashti et al. (2015) studied by means of NLFEA the behavior of rectangular RC walls subjected to uni-directional (in-plane) horizontal cyclic loading.

The present paper focus on the behavior of walls subjected to bidirectional (in-plane and out-of-plane) horizontal loading, addressing in particular the influence of out-of-plane instability that can occur for thin members.

For this purpose, the experimental response of two test units was compared with the results of
NLFEA. The latter are carried out using two different crack models, a "Fixed crack model" and a "Rotating crack model", in order to highlight the differences between them.

\section{NLFE MODEL DESCRIPTION}

The analyses herein shown were performed with DIANA 10 (Manie 2015). According to (Belletti et al. 2014), concrete was modelled using 4 nodes curved shell elements (named Q20SH in DIANA) with 4 Gauss integration points over the element area and 5 Simpson integration points over the element thickness. Reinforcing bars were modelled using embedded reinforcement considering perfect bond between reinforcement and concrete. Each bar element is characterized by 2 Gauss integration points along the truss axis.

\subsection{Concrete model}

The Total Strain Crack Model, available in DIANA (Manie 2015), was used to model the concrete behaviour. Moreover, two different approaches were analysed in this paper: the "Fixed crack model" approach and the "Rotating crack model" approach.

For concrete in tension an exponential behaviour based on the definition of the fracture energy in tension, $G_{F}$, and of the crack bandwidth, $h$, have been adopted. $G_{F}$ was calculated according to the proposal in fib-Model Code 2010 while $h$ was assumed equal to the square root of the area of each element, as suggested by Guidelines for Non-linear Finite Element Analyses (2012).

For concrete in compression two different stressstrain relationships were used. The behaviour of unconfined concrete has been modelled with a parabolic relationship, according to (Feenstra 1993), based on the definition of the crack bandwidth, $h$, and of the fracture energy in compression, $G_{C}$, assumed equal to 250 times $G_{F}$ (Nakamura \& Higai, 2001). The confinement effect due to the presence of stirrups in the boundary elements of some of the analysed walls was taken into account adopting the model proposed by Mander et al. (1988), as shown in Figure 2.

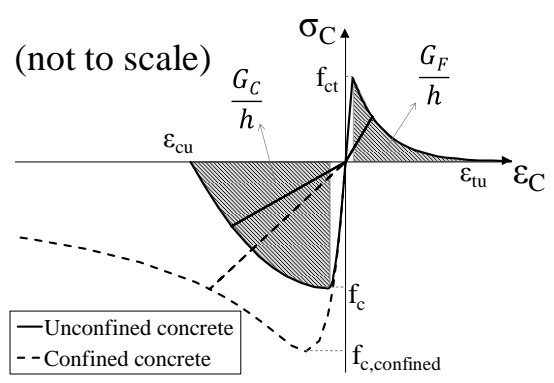

Figure 2 - Constitutive model adopted for confined and unconfined concrete / Legame costitutivo adottato per calcestruzzo confinato e non confinato.

The reduction of the compressive strength of concrete, due to tensile strains perpendicular to the prin- 
cipal compressive direction, was taken into account according to Vecchio \& Collins (1993). These authors fix the lower bound of this reduction curve in 0.6 .

For what regards the fixed crack model, due to the fact that after cracking the reference coordinate system is fixed and determined by the crack direction, shear stresses and strains developed along the crack. In this paper the shear stiffness after cracking is reduced using a constant shear retention factor, equal to 0.03 , that multiplies the elastic shear modulus of concrete.

\subsection{Steel model}

The cyclic behaviour of steel was considered using the Monti-Nuti model (Monti \& Nuti 1992) available in DIANA, Figure 3.

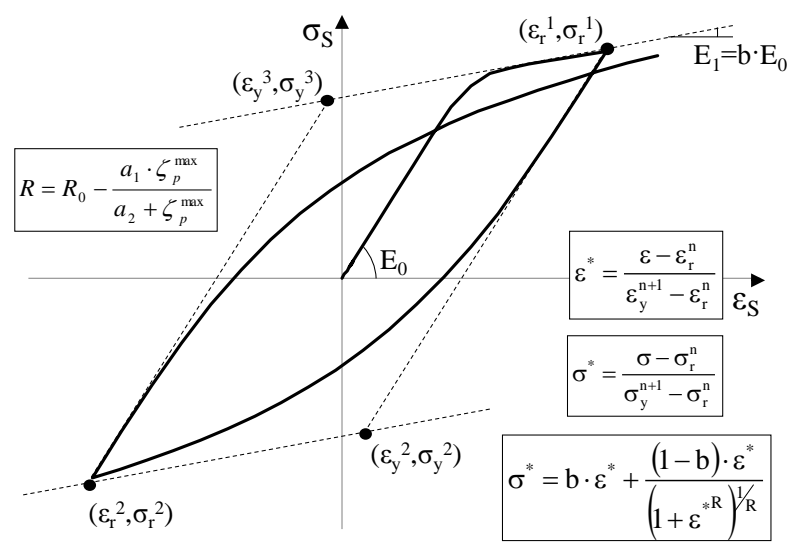

Figure 3 - Monti-Nuti model adopted for steel modeling / Modello di Monti-Nuti adottato per la modellazione dell'acciaio

The model proposed by Monti and Nuti is expressed in terms of a dimensionless stress $\sigma^{*}$ and strain $\varepsilon^{*}$. The curvature parameter $\mathrm{R}$ is a function of the initial curvature $R_{0}$, of the maximum plastic excursion developed $\zeta_{\mathrm{p}}{ }^{\max }$ and of two material parameters $\mathrm{a}_{1}$ and $\mathrm{a}_{2}$. In order to investigate the influence of these parameters on the stress-strain relationship a preliminary parametric study was carried out.

The parametric study was based on the experimental campaign carried out on $\phi 12$ bars tested at the ETH Zurich by Thiele et al. (2001), Figure 4.
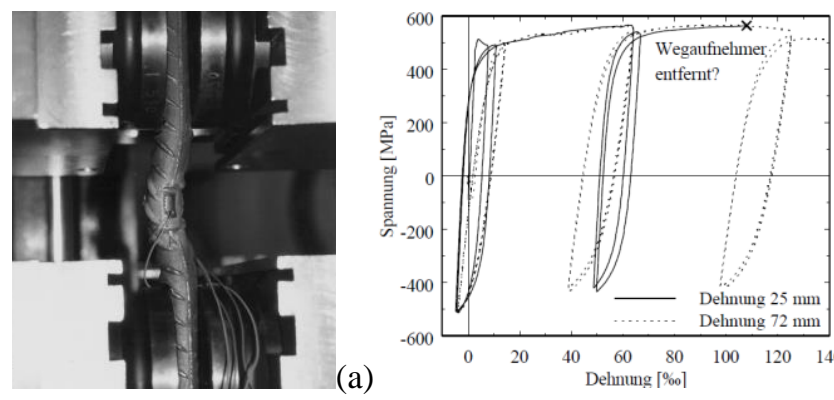

Figure 4 - Reference experimental campaign for parametric study on Monti-Nuti parameters: (a) experimental set-up, (b) experimental results / Campagna sperimentale di riferimento per lo studio parametrico sul modello di Monti-Nuti: (a) set-up sperimentale, (b) risultati. (Thiele et al. 2001)
The reference parameters, according to Fragiadakis et al. (2007), were set equal to $R 0=20, a_{1}=18.45$ and $\mathrm{a}_{2}=0.15$. In the following the results obtained by changing the parameter R0 (Figure 5-a), the parameter $\mathrm{a}_{1}$ (Figure 5-b), and the parameter $\mathrm{a}_{2}$ (Figure 5-c) are reported.
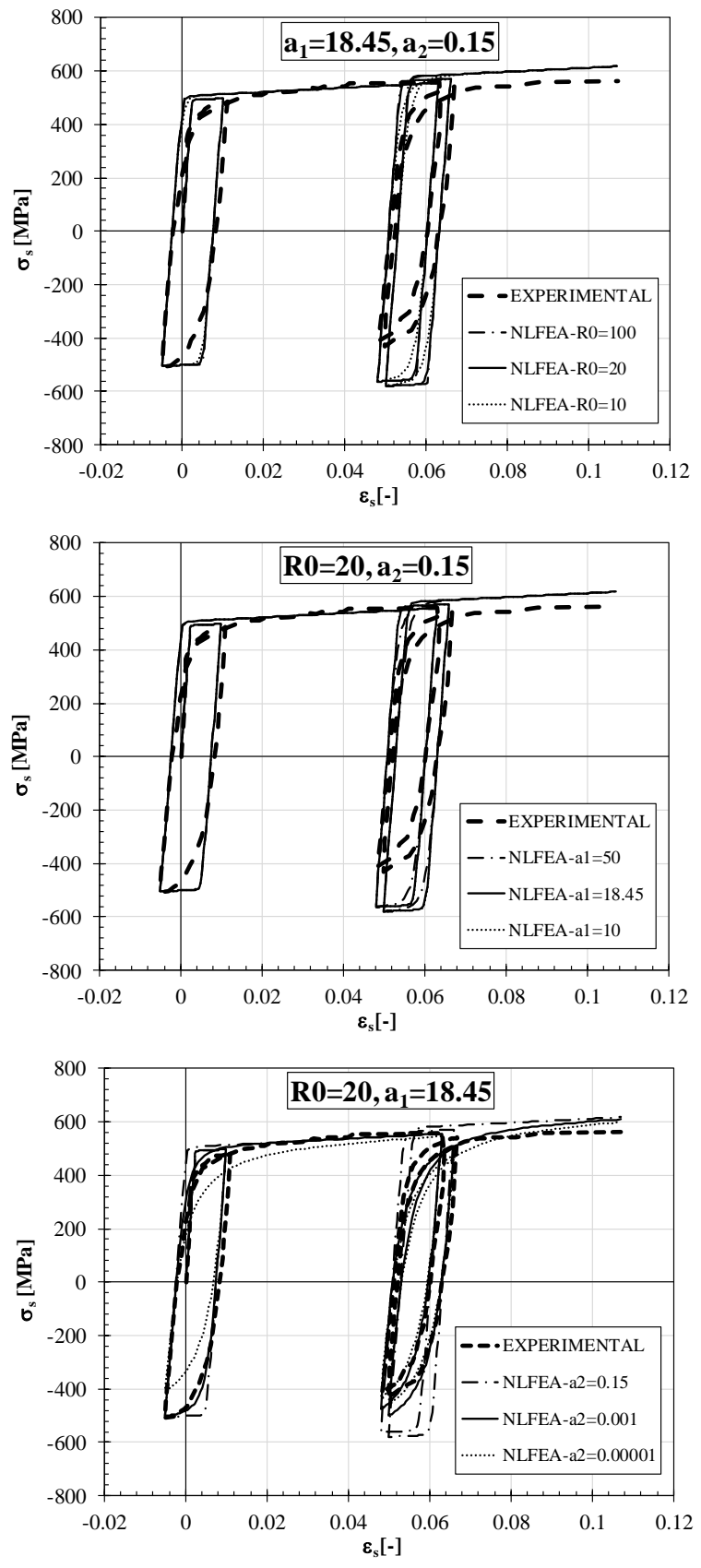

Figure 5 - Parametric studies on Monti-Nuti model: (a) influence of R0, (b) influence of a1, (c) influence of a2 / Studio parametrico sul modello Monti-Nuti: (a) influenza di R0, (binfluenza di a1, (c) influenza di a2.

From Figure 5-a it can be seen that the increasing of the parameter R0 leads to an increasing of the curvature of the stress-strain relationship, even if the scatter in NLFEA results is rather small and all the curves obtained by means of NLFEA do not quite match the experimental results.

The results reported in Figure 5-b highlight how increasing the $a_{1}$ parameter the curvature decrease. Also in this case the scatter between the experi- 
mental and the NLFEA results is relatively large for all the different values of the $a_{1}$ parameter.

Finally, the curves reported in Figure 5-c shown that the slope of the stress-strain relationship strongly depends on the $\mathrm{a}_{2}$ parameter. In particular assuming $a_{2}=0.001$ the NLFEA curve fits well the experimental results. For this reason, the following final set of parameters $\left(\mathrm{R} 0=20, \mathrm{a}_{1}=18.45\right.$ and $\left.\mathrm{a}_{2}=0.001\right)$ will be used for the analyses of the walls.

\section{CASE STUDIES}

Two different case studies were analysed in this paper: a thin T-shaped RC wall, TW4 (Rosso et al. 2015), and a U-shaped RC wall, TUC (Constantin \& Beyer 2016).

\subsection{TW4}

\subsubsection{Experimental set-up}

TW4 is a T-shaped RC wall that was tested at EPFL (Rosso et al. 2015). TW4 is a 2:3 scale wall subjected to a combination of in-plane and out-ofplane quasi-static cyclic loading. The wall was 2000 $\mathrm{mm}$ tall, $80 \mathrm{~mm}$ thick and $2700 \mathrm{~mm}$ long. At the north end (see Figure 6) the wall presented a flange $80 \mathrm{~mm}$ thick and $440 \mathrm{~mm}$ long. The foundation was $3600 \mathrm{~mm}$ long, $700 \mathrm{~mm}$ thick and $400 \mathrm{~mm}$ tall, while the top RC beam was $3160 \mathrm{~mm}$ long, $440 \mathrm{~mm}$ thick and $420 \mathrm{~mm}$ tall, Figure 6.

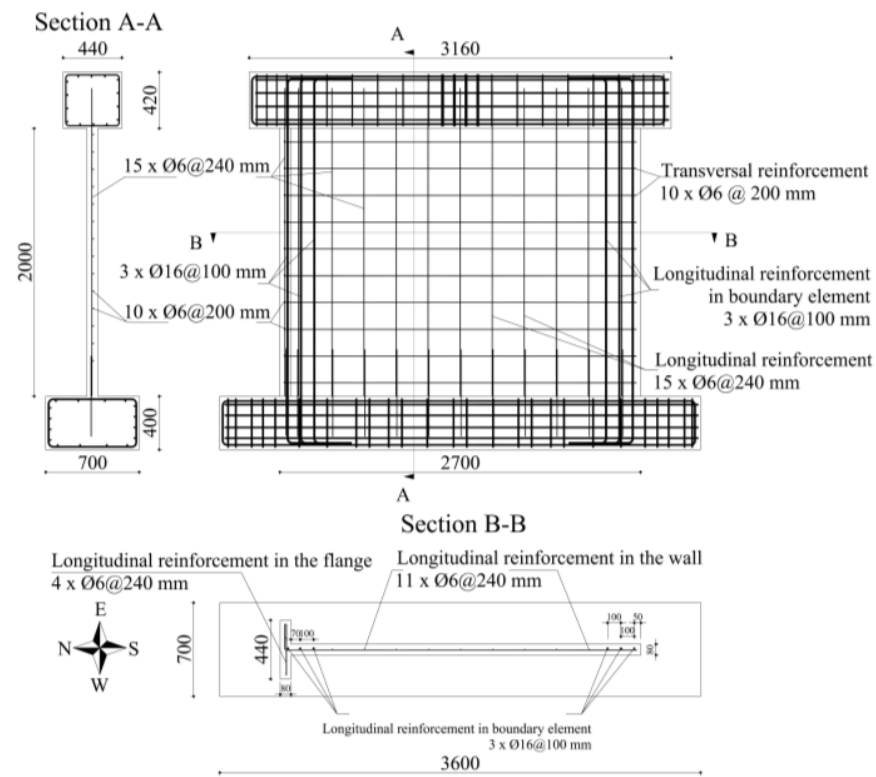

Figure 6 - Geometrical characterization and detailing of TW4 wall (measure in cm) / Dettagli geometrici del provino TW4

Figure 6 also reports the reinforcement details, which follow current design practices in Colombia. According to these detailing practices the reinforcement consisted of a single layer of grid reinforcement, characterized by a slight eccentricity with respect to the centerline of the section. The detail of the eccentricity of the rebar layer is shown in Figure 7.

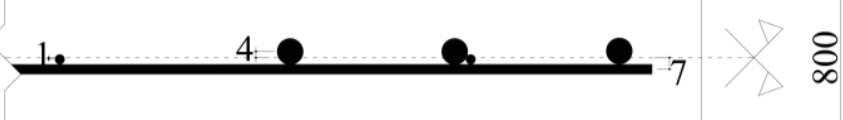

Figure 7 - Detail of the eccentricity of the single layer of reinforcement for specimen TW4 (measure in $\mathrm{mm}$ ) / Dettaglio dell'eccentricità del singolo strato di armature presente nel provino TW4 (valori in $\mathrm{mm}$ )

The longitudinal reinforcement is characterized by $\phi 6$ bars spaced of $240 \mathrm{~mm}$, moreover both the extremities of the wall (the so-called boundary elements) were over reinforced with 3 longitudinal rebars of $16 \mathrm{~mm}$. The transversal reinforcement is characterized by $\phi 6$ bars spaced of $200 \mathrm{~mm}$

During the test the axial load ratio was maintained constant and equal to 5\% (equivalent to an applied constant axial force of $330 \mathrm{kN}$ ).

The test unit was subjected to horizontal bidirectional loading (in-plane and out-of-plane). The in-plane load was applied with a shear span of $10 \mathrm{~m}$, achieved by coupling an horizontal actuator to impose the in-plane loading and two vertical actuators, acting on the wall ends, to impose the required bending moment. Two additional horizontal actuators were connected to the top beam to impose the horizontal out-of-plane displacement. The applied loading history is reported in Figure 8.

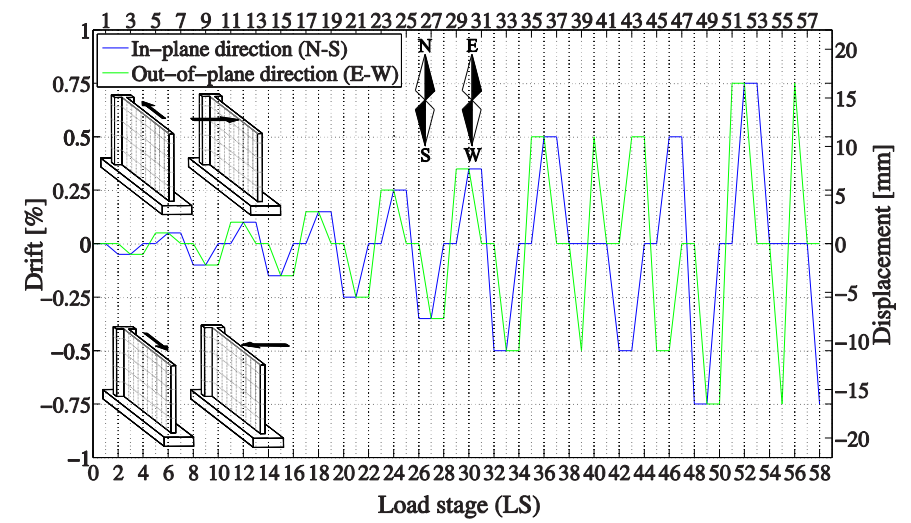

Figure 8 - Loading history applied for test unit TW4 / Storia di carico applicata alla parete TW4 (Rosso et al. 2015).

The material properties, derived from material tests, as well as the model parameters, for both concrete and steel are listed in Table 1.

Table 1 - Main mechanical properties derived from material tests and model parameters for test unit TW4/ TW4, principali caratteristiche meccaniche derivate dai test sui materiali e parametri usati per NLFEA

\begin{tabular}{l|ccc|cccc} 
& \multicolumn{3}{|c|}{ From material tests } & \multicolumn{4}{|c}{ Calculated and used for NLFEA } \\
\hline & $\begin{array}{c}\mathbf{f}_{\mathbf{y}} \\
{[\mathbf{M p a}]}\end{array}$ & $\begin{array}{c}\mathbf{f}_{\mathbf{u}} \\
{[\mathbf{M p a}]}\end{array}$ & $\begin{array}{c}\mathbf{E}_{\mathbf{s}} \\
{[\mathbf{G p a}]}\end{array}$ & $\mathbf{b}[-]$ & $\mathbf{R 0}[-]$ & $\mathbf{a}_{\mathbf{1}}[-]$ & $\mathbf{a}_{\mathbf{2}}[-]$ \\
\hline STEEL $\phi 6$ & 460 & 625 & 183.5 & 0.009 & 20 & 18.45 & 0.001 \\
STEEL $\phi 16$ & 565 & 650 & 208.1 & 0.005 & 20 & 18.45 & 0.001 \\
\hline & $\mathbf{f}_{\mathbf{c}}$ & $\mathbf{E}_{\mathbf{c}}$ & $\mathbf{f}_{\mathbf{c t}}$ & $\mathbf{G}_{\mathbf{F}}$ & $\mathbf{G}_{\mathbf{C}}$ & shear retention \\
& {$[\mathbf{M p a}]$} & {$[\mathbf{G p a}]$} & {$[\mathbf{M p a}]$} & {$[\mathbf{N} / \mathbf{m m}]$} & {$[\mathbf{N} / \mathbf{m m}]$} & factor [-] \\
\hline CONCRETE & 31.2 & 29.2 & 1.46 & 0.1356 & 33.9 & 0.03
\end{tabular}




\subsubsection{NLFE model}

A sketch of the model used for NLFEA is depicted in Figure 9.

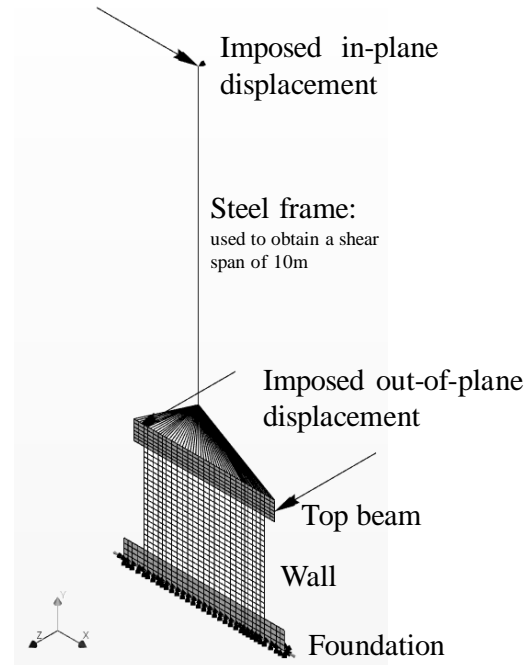

Figure 9 - TW4, NLFE model / TW4, modello utilizzato per le analisi non lineari

The foundation and the top beam were modelled with concrete adopting an elastic behaviour while the wall was modelled with nonlinear behaviour for concrete and steel, according to the stress-strain relationships shown in Figure 10, which are computed with the material properties listed in Table 1.

The steel frame indicated in Figure 9 was adopted in the NLFE to simulate the applied experimental shear span of $10 \mathrm{~m}$. This frame is obtained using 2node beam elements, with 2 Gauss integration points along the beam axis each, connected to the upper part of the top RC beam with a hinged connection. The legitimacy of this frame modelling approach was validated by verifying the ratio between shear and bending moment at the base of the wall.
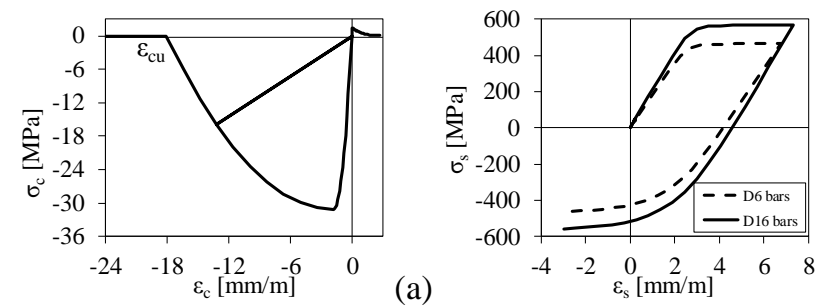

Figure 10 - TW4, constitutive models for (a) concrete and (b) steel / TW4, modelli costuitutivi per (a) calcestruzzo e (b) acciaio

\subsubsection{NLFE results}

Figure 11 describes the comparison between experimental results and NLFEA results for both "Fixed crack model" and "Rotating crack model" in terms of in-plane force $v s$ displacement response. The points in which NLFEA reached the crushing of concrete are also signaled. Crushing of concrete is attained when the compressive strain of concrete reaches the ultimate value, $\varepsilon_{c u}$, Figure 10 -a.

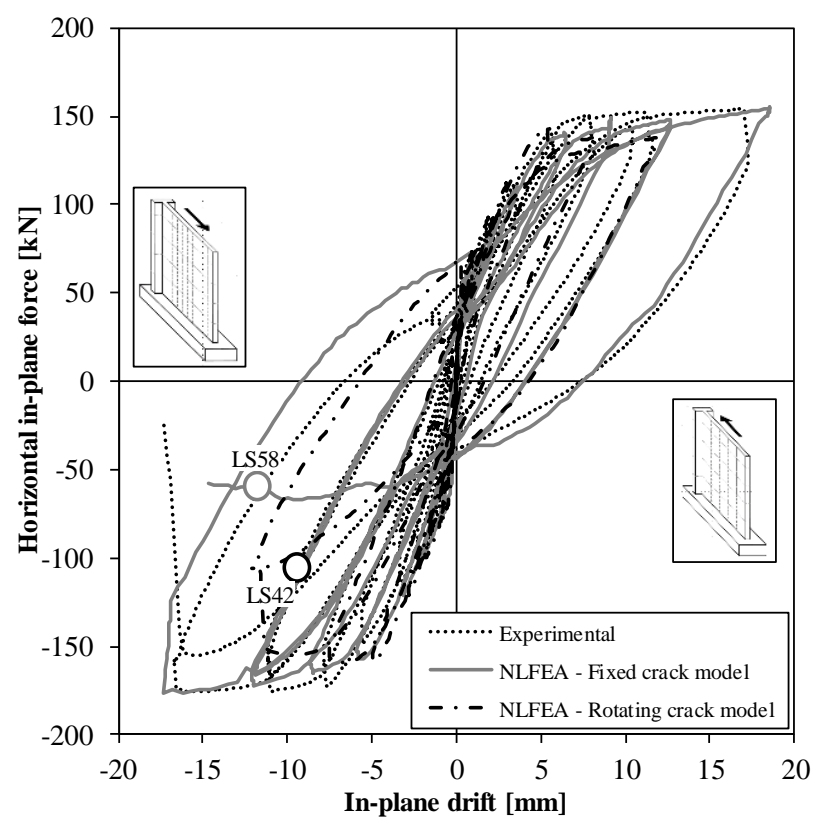

Figure 11 - TW4, in-plane force $v s$ displacement response: comparison between experimental and NLFEA results / TW4, grafico forza vs spostamento nel piano: confronto tra risultati sperimentali e NLFEA

The results reported in Figure 11 show that both the "Fixed crack model" and the "Rotating crack model" are able to predict the experimental response. Moreover, the "Rotating crack model" failed at LS42 (corresponding to $-0.5 \%$ in-plane drift) as a result of the crushing of concrete at the base of the boundary element (Figure 12-a), while the "Fixed crack model" failed at LS58 (corresponding to $0.75 \%$ in-plane drift) as a result of crushing of concrete triggered by damage induced by out-of-plane deformations (Figure 12-c), which is the same failure mode that was experimentally observed (Figure 12-b).
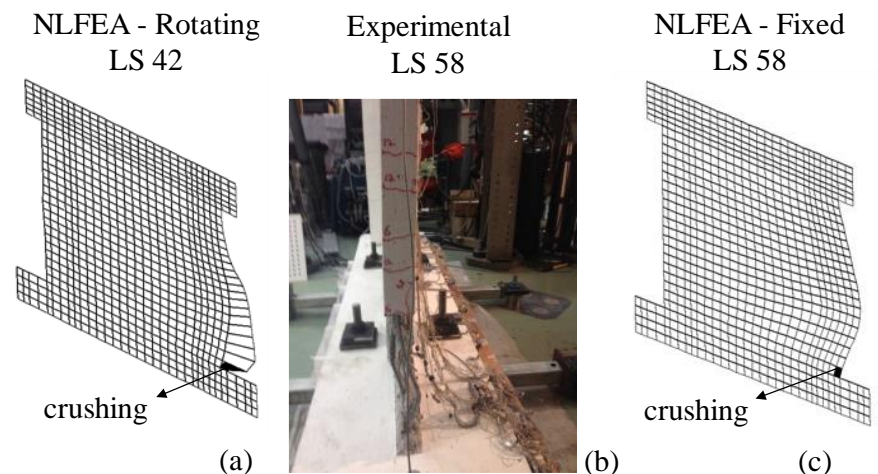

(a)

Figure 12 - TW4, failure modes: (a) NLFEA Rotating crack model, (b) Experimentally observed, and (c) NLFEA Fixed crack model (the contour in NLFEA results represent the compressive strain) / TW4, modalità di rottura: (a) NLFEA modello fessurativo rotante, (b) sperimentale e (c) NLFEA modello fessurativo fisso.

This fact can be explained considering that for the "Rotating crack model" the stress-strain relationship is evaluated in the principal direction also upon cracking, while for the "Fixed crack model" the reference system in which the stress-strain relationship is evaluated remains fixed upon cracking and thus a 
shear strain occurs that leads to the reduction of the compressive strain.

In order to highlight this a further analysis was carried out using the "Rotating crack model" by increasing the fracture energy in compression, $G_{C}$, from 250 times $G_{F}(33.9 \mathrm{~N} / \mathrm{mm})$ to 500 times $G_{F}$ $(67.8 \mathrm{~N} / \mathrm{mm})$, where $G_{F}$ represents the fracture energy in tension. The results are reported in Figure 13.

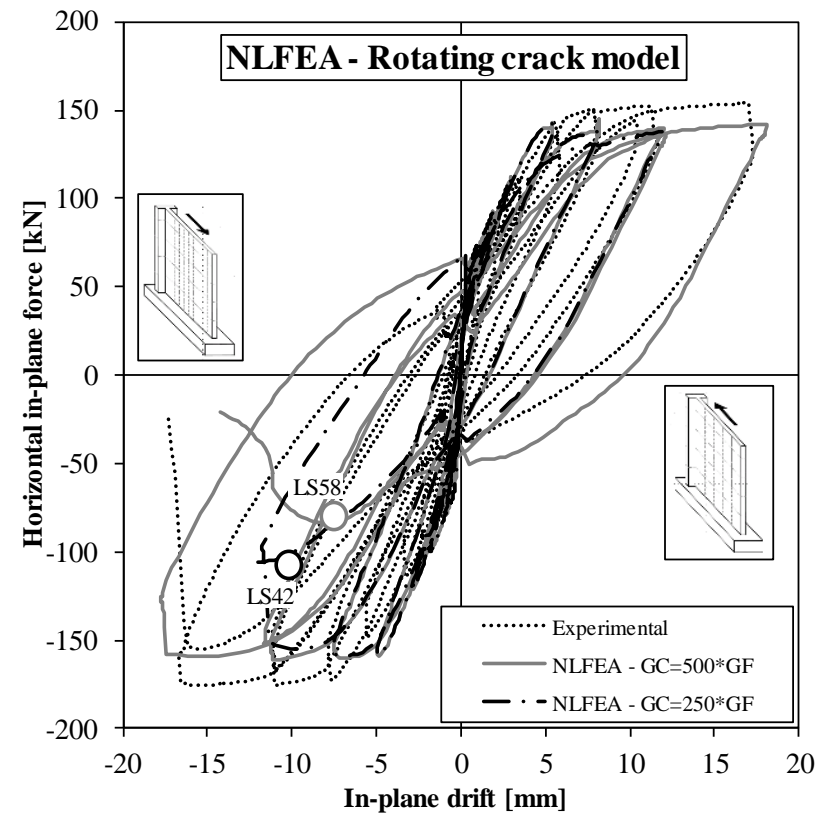

Figure 13 - TW4, influence of fracture energy in compression on "Rotating crack model" / TW4, influenza dell'energia di frattura a compressione per il modello a fessurazione rotante

Figure 13 shows that by increasing the fracture energy in compression the results obtained using the "Rotating crack model" are quite similar to the results obtained using the "Fixed crack model" and also the experimental results. Assuming the fracture energy in compression equal to 500 times $G_{F}$, failure occurs at LS58 (corresponding to $-0.75 \%$ in-plane drift) due to the crushing of concrete in the compressive edge of the wall, which is in accordance with the experimental outcomes.

The mechanism of out-of-plane instability, as analytically described by Goodsir (1985) and experimentally confirmed by Rosso et al. (2015), occurred after the development of large tensile strains in the boundary element; due to the cyclic load applied, when the boundary element is reloaded in compression and before cracks close, the compression force is supported only by the vertical reinforcement potentially leading to out-of-plane instability. For this reason, the comparison between NLFEA and experimental results is extended to the evaluation of the out-of-plane displacement along the height of the wall in two different significant load steps, namely LS38 and LS47-48 when the load is applied from the flange to the free edge of the wall and in correspondence of an in-plane drift of $0 \mathrm{~mm}$, when the out-ofplane was maximum.

The results reported in Figure 14 are obtained using for the "Fixed crack model" $G_{C}=250 \cdot G_{F}$ (33.9
$\mathrm{N} / \mathrm{mm}$ ) and for the "Rotating crack model" $G_{C}=500 \cdot G_{F}(67.8 \mathrm{~N} / \mathrm{mm})$.

From Figure 14 it can be noted that both the "Fixed crack model" and the "Rotating crack model" are able to satisfactorily simulate the overall out-ofplane behaviour of the wall even if for the "Fixed crack model" the maximum out-of-plane displacement was detected at a lower height when compared with the experimental results and the "Rotating crack model" results.
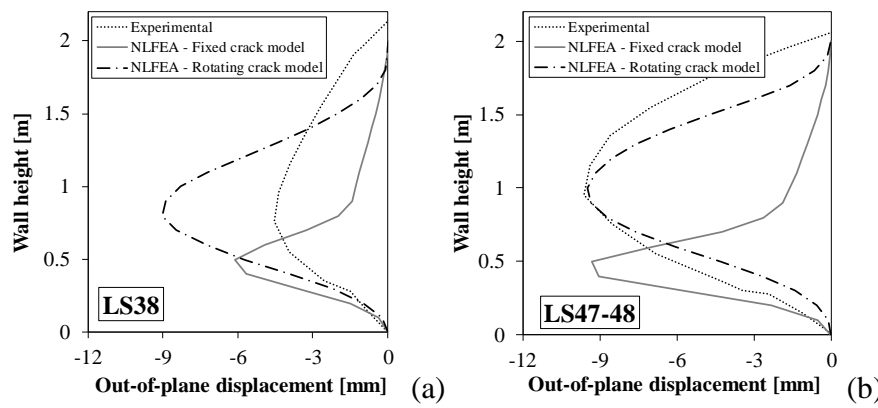

Figure 14 - TW4, out-of-plane displacement along the height of the wall: (a) LS38 and (b) LS47-48 / TW4, spostamenti fuori dal piano lungo l'altezza della parete: (a) LS38 e (b) LS47-48

\subsection{TUC}

\subsubsection{Experimental set-up}

TUC is a U-shaped RC wall tested at EPFL (Constantin \& Beyer 2016) and represents an half-scale model of the lower two stories of a prototype elevator shaft, Figure 15.
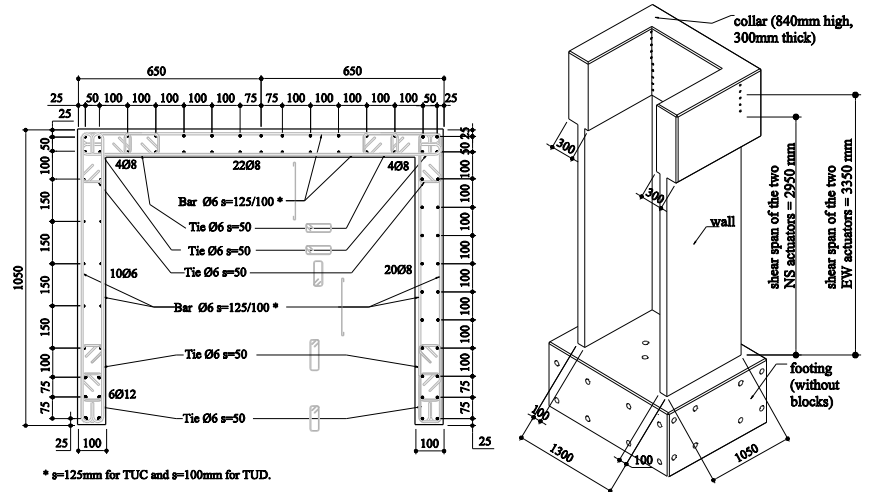

Figure 15 - Geometrical characterization and detailing of TUC wall / Proprietà geometriche della parete TUC (Constantin \& Beyer 2016)

The transversal reinforcement is characterized by stirrups with a diameter of $6 \mathrm{~mm}$ spaced of $125 \mathrm{~mm}$. Moreover, the extremities of the flanges, defined later as boundary elements, and the corners between the web and the flanges, are over reinforced with additional stirrups with a diameter of $6 \mathrm{~mm}$ spaced of $50 \mathrm{~mm}$.

The longitudinal reinforcement was set different for the two flanges. One flange was detailed with vertical reinforcement mainly concentrated in the boundary elements while in the other flange and in the web the vertical reinforcement was uniformly distributed. The total reinforcement percentage for 
the flanges is approximatively the same, as listed in Table 2.

Table 2 - TUC, vertical reinforcement percentage / TUC, rapporto di armatura verticale

\begin{tabular}{lccc}
\hline & $\rho_{\mathrm{v}}$ total $^{1}$ & $\rho_{\mathrm{v}}$ conf. & $\rho_{\mathrm{v}}$ unconf. \\
\hline Flange with distributed reinf. (East) & $1.06 \%$ & $1.34 \%$ & $0.91 \%$ \\
Flange with concentrated reinf. (West) & $1.01 \%$ & $2.45 \%$ & $0.31 \%$ \\
Web & $1.16 \%$ & $1.25 / 0.9 \%$ & $1.00 \%$ \\
Entire wall & $1.09 \%$ & - & - \\
\hline
\end{tabular}

${ }^{1} \rho_{\mathrm{v}}$ was computed by counting the corners towards the web

2 due to differencies in flange reinforcement layouts reinforcement contents of confined corner regions differ slightly between the two corners

During the test the specimen was subjected to an axial load ratio of 0.06 (equivalent to an axial force of $806 \mathrm{kN}$ ).

The horizontal load is applied by means of three actuators: the EW actuator loaded the web at a height of $h_{E W}=3.35 \mathrm{~m}$ while the NS actuators loaded the flanges at a height of $h_{N S}=2.95 \mathrm{~m}$.

As the key objective of the experimental investigation was to understand the behaviour of the wall under diagonal loading, the main cycles were applied along the two diagonals. The detail of the applied loading history is reported in Figure 16 with the definition of the loading directions adopted.
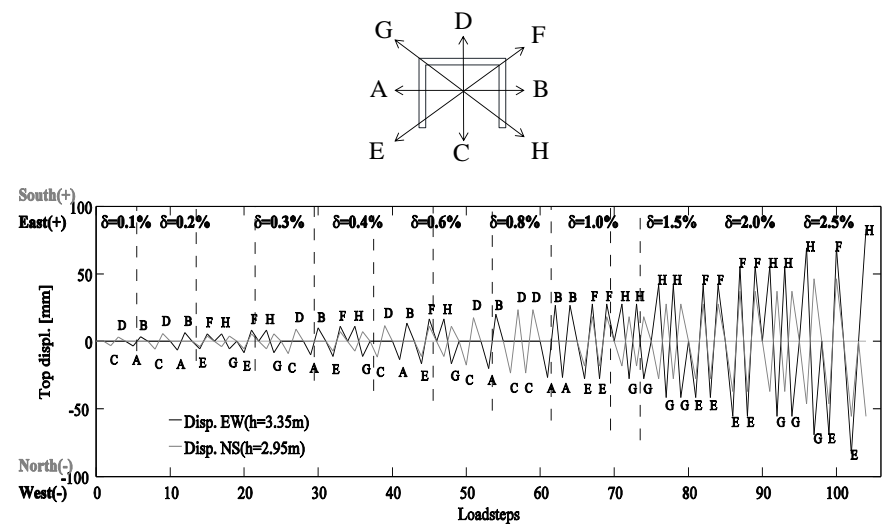

Figure 16 - TUC, loading history / TUC, storia di carico (Constantin \& Beyer 2016)

The material properties and model parameters for both concrete and steel are listed in Table 3.

Table 3 - TUC, material properties / TUC, proprietà dei materiali

\begin{tabular}{l|ccc|cccc} 
& \multicolumn{4}{|c|}{ From material tests } & \multicolumn{4}{c}{ Calculated and used for NLFEA } \\
\hline & $\begin{array}{c}\mathbf{f}_{\mathbf{y}} \\
{[\mathbf{M p a}]}\end{array}$ & $\begin{array}{c}\mathbf{f}_{\mathbf{u}} \\
{[\mathbf{M p a}]}\end{array}$ & $\begin{array}{c}\mathbf{E}_{\mathbf{s}} \\
{[\mathbf{G p a}]}\end{array}$ & $\mathbf{b}[-]$ & $\mathbf{R 0}[-]$ & $\mathbf{a}_{\mathbf{1}}[-]$ & $\mathbf{a}_{\mathbf{2}}[-]$ \\
\hline STEEL $\phi 6$ & 492 & 623 & 200 & 0.009 & 20 & 18.45 & 0.001 \\
STEEL $\phi 8$ & 563 & 663 & 200 & 0.007 & 20 & 18.45 & 0.001 \\
STEEL $\phi 12$ & 529 & 633 & 200 & 0.006 & 20 & 18.45 & 0.001 \\
\hline & $\mathbf{f}_{\mathbf{c}}$ & $\mathbf{\mathbf { E } _ { \mathbf { c } }}$ & $\mathbf{f}_{\mathbf{c t}}$ & $\mathbf{f}_{\mathbf{c}, \mathbf{c o n f}}$ & $\mathbf{G}_{\mathbf{F}}$ & $\mathbf{G}_{\mathbf{C}}$ & shear \\
& {$[\mathbf{M p a}]$} & {$[\mathbf{G p a}]$} & {$[\mathbf{M p a}]$} & {$[\mathbf{M p a}]$} & {$[\mathbf{N} / \mathbf{m m}]$} & {$[\mathbf{N} / \mathbf{m m}]$} & retention [-] \\
\hline CONCRETE & 42 & 31.6 & 3.2 & 50.7 & 0.14 & 35 & 0.03
\end{tabular}

\subsubsection{NLFE model}

The model used for the NLFEA is represented in Figure 17. Three different regions are considered in the model: the upper collar, made of elastic material, the confined concrete, in the zones characterized by the presence of additional stirrups, and the unconfined concrete, in the remaining zones. The influence of the foundation is neglected and hence the model restraints are located at the base nodes of the wall.

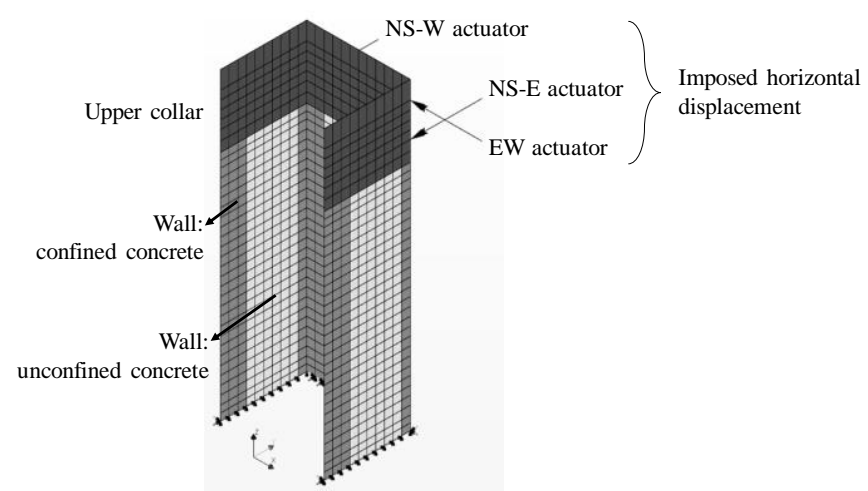

Figure 17 - TUC, sketch of NLFE model / TUC, modello per analisi non lineari ad elementi finiti

The constitutive relationships adopted in NLFEA are based on the model parameters listed in Table 3. They were defined following the formulations proposed above in $\S 2$ and are illustrated in Figure 18.
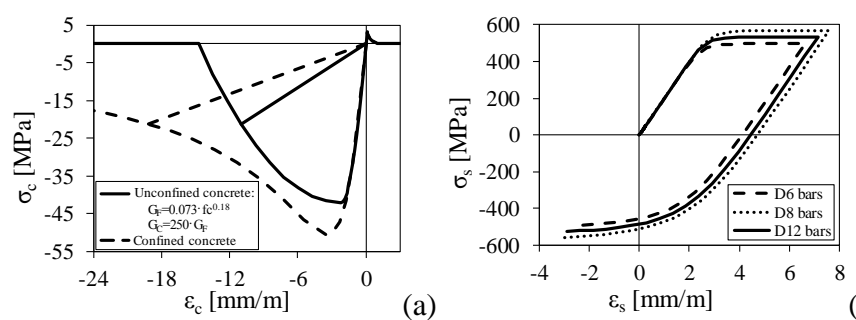

(b)

Figure 18 - TUC, constitutive models for a) concrete and b) steel / TUC, modelli costitutivi per a) calcestruzzo e b) acciaio

\subsubsection{NLFE results}

Figure 19 and Figure 20 describe the comparison between experimental results and NLFEA results for both "Fixed crack model" and "Rotating crack model" in terms of SRSS force $v s$ displacement response when load is applied along the E-F diagonal and $\mathrm{H}-$ $\mathrm{G}$ diagonal respectively; the points in which the NLFEA failed due to crushing of compressive concrete are also indicated. The SRSS values were multiplied by the sign of the NS displacement for plotting the hysteresis loop consistently.

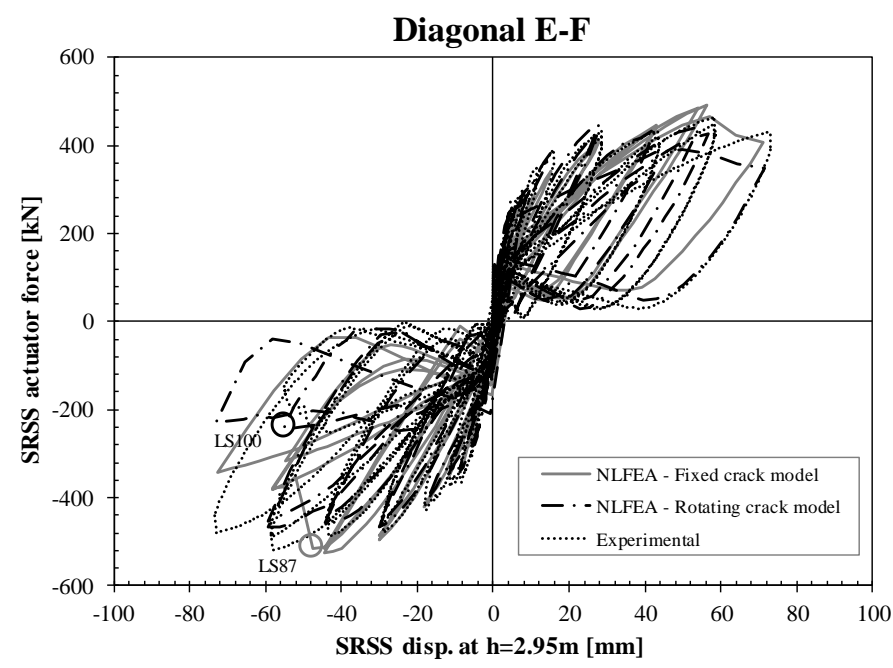

Figure 19 - TUC, SRSS force $v s$ displacement along diagonal E-F / TUC, SRSS forza-spostamento lungo la diagonal E-F 


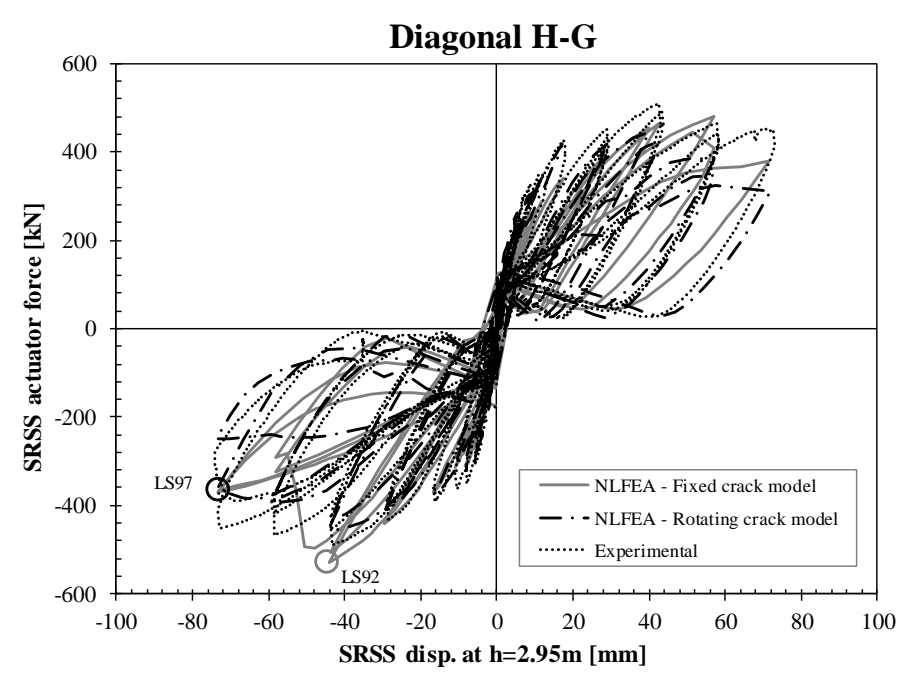

Figure 20 - TUC, SRSS force $v s$ displacement along diagonal H-G / TUC, SRSS forza-spostamento lungo la diagonale H-G

The results plotted in Figure 19 and Figure 20 show that in both directions the "Fixed crack model" failed before the "Rotating crack model", which is opposite to what had been observed for the previous test unit TW4. In particular, from Figure 19 the "Fixed crack model" reached concrete crushing in the unconfined zone of the East flange at LS87 $(\delta=2 \%)$ while the "Rotating crack model" reached the crushing of concrete at LS100 $(\delta=2.5 \%)$. The same remark can be done analysing the specimen loaded along the diagonal H-G, Figure 20. This fact can be explained considering that for the "Rotating crack model" the compressive strain in the flanges are mainly concentrated in the confined zone while, for the "Fixed crack model", the shear behaviour defined once the first cracking is formed tend to distribute the compressive strain along the whole flange.

In Figure 21 the vertical strains on the inner and outer side of the flange ends, along the height of the wall, are investigated. These vertical strains, obtained for diagonal loading at drift of $1 \%$, were derived from NLFEA and compared with experimental outcomes.

Figure 21 shows that both the "Rotating crack model" and the "Fixed crack model" are in good agreement with the experimental results. In particular, from Figure 21 it can be observed that when the flange ends are in compression (Pos. E and Pos. H) the compressive strains at the base of the wall on the outer face are $\sim 2$ times larger than on the inner face, Figure 21-a and Figure 21-c. On the other end, when the flange ends are in tension (Pos. F and Pos. G) the tensile strains in the outer face ends are close to the tensile trains in the inner face ends, Figure 21-b and Figure 21-d. The good agreement obtained comparing NLFEA and experimental results in terms of vertical strains in the inner and outer sides of the flange is encouraging for the application of the current model in future parametric studies. Note that the large strain gradient under diagonal loading, exhibited when the flange ends are in compression, pro- motes the occurrence of local out-of-plane buckling of the wall, which was observed in the experimental test.
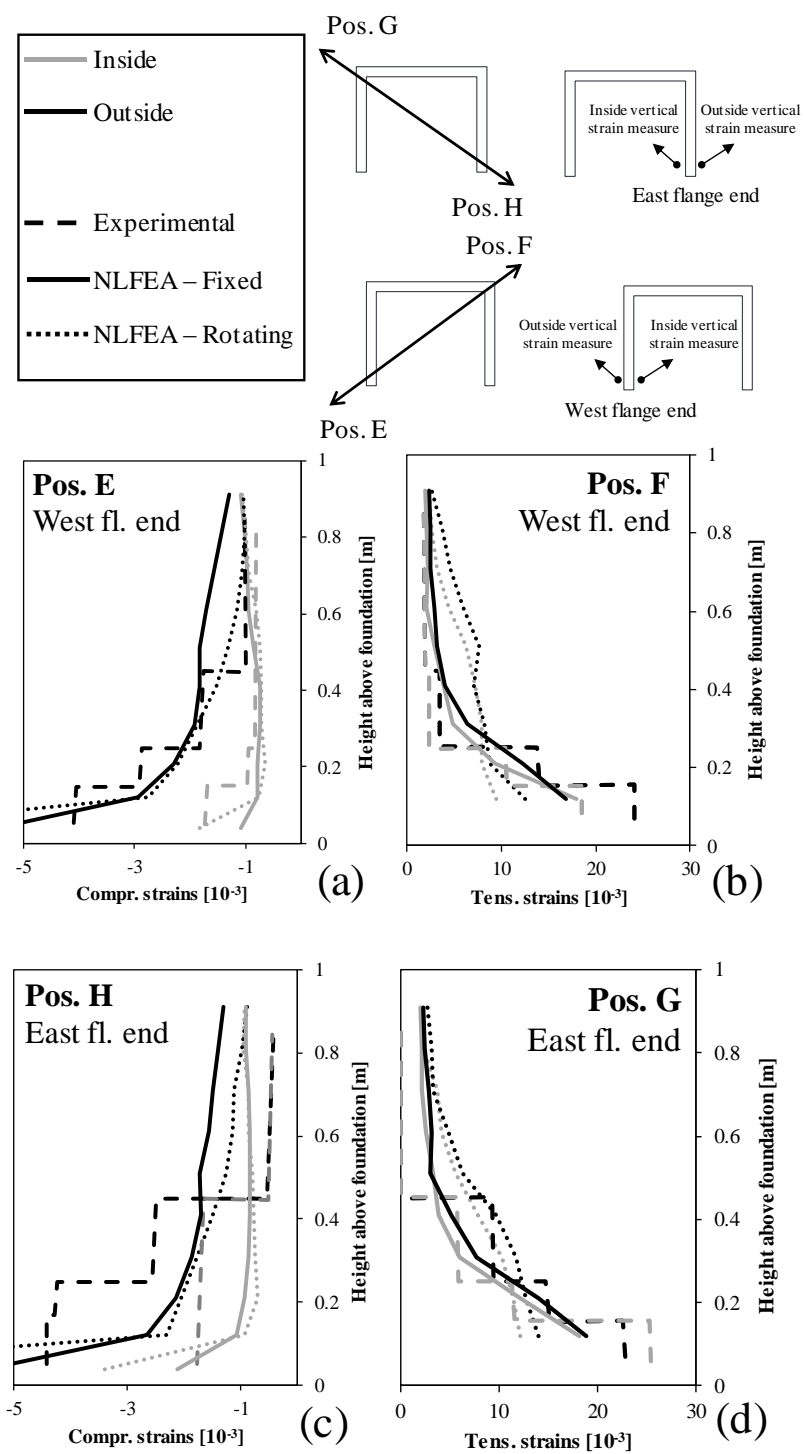

Figure 21 - TUC, comparison between experimental and NLFEA results: vertical strains on the inner and outer side of the flange computed along the height / TUC, confronto tra risultati sperimentali e analisi non lineari ad elementi finiti: deformazioni verticali nelle facce interne ed esterne di entrambe le estremità delle flange.

\section{CONCLUSIONS}

In this paper the bidirectional response of reinforced concrete walls was investigated by means of NLFEA (nonlinear finite element analyses). The need for this research arises from the observed lack of numerical and experimental studies on this topic. The interaction of bidirectional loading with out-ofplane instability modes of thin walls was also considered.

The results demonstrate that NLFEA using curved shell elements and appropriately calibrated material constitutive models are able to predict not only the global behaviour of $\mathrm{RC}$ walls but also their local response. It thus seems logical to use this advanced numerical tool to further study wall configu- 
rations that are able to optimize the response under bidirectional loading. In particular, the influence of the content and detailing of longitudinal reinforcing bars, the confining effect due to the increase of stirrups, and the width of confined zone in the boundary elements should be addressed. The analyses of different boundary and loading conditions and the evaluation of the effect of slabs and torsional loading will also be carried out. / Nella presente memoria è stato studiato, per mezzo di NLFEA, il comportamentobidirezionale di pareti sottili in calcestruzzo armato soggette a carichi ciclici. La necessità di questa ricerca nasce dalle carenze di studi sperimentali e numerici su questo argomento. Nella presente memoria è stata inoltre considerata l'interazione tra carichi bidirezionali e instabilità fuori dal piano delle pareti.

I risultati ottenuti dimostrano che le analisi non lineari, con elementi shell e con modelli costitutivi dei materiali calibrati in maniera appropriata, sono in grado di cogliere non solo il comportamento globale di pareti snelle ma anche i fenomeni locali.

Per questo motivo il presente lavoro vuole essere la base per futuri studi volti ad investigare l'effetto di differenti parametri che possono influenzare la risposta di pareti sotto carichi bidirezionali. In particolare verranno valutate l'influenza della quantità e della posizione delle armature, l'effetto di confinamento dato dalle staffe e l'ampiezza della zona confinata alle estremità delle pareti. Le ricerche future saranno inoltre estese alla valutazione di diverse condizioni vincolari e di carico, considerando l'effetto delle piastre di interpiano e di azioni torsionali.

\section{REFERENCES}

Belletti B., Damoni C., Gasperi A. (2013) Modeling approaches suitable for pushover analyses of RC structural wall buildings. Engineering Structures, 57(12): 327-338;

Damoni C., Belletti B., Esposito R. (2014a). Numerical prediction of the response of a squat shear wall subjected to monotonic loading. European Journal of Environmental and Civil Engineering, 18(7): 754-769;

Belletti B., Damoni C., Hendriks M.A.N., De Boer A.. (2014b). Analytical and numerical evaluation of the design shear resistance of reinforced concrete slabs. Structural Concrete, 15(3): 317-330;

Belletti B., Scolari M., Vecchi F. (2016a). Nonlinear static and dynamic finite element analyses of reinforced concrete shear walls using PARC_CL crack model. FraMCoS-9.

Belletti B., Stocchi A., Scolari M., (2016b). Shell modelling of a 1/13 scaled RC containment vessel under cyclic actions with PARC_CL crack model. 8th International CONSEC, Lecco, Italy, 12-14 September.

CEN (2004) Eurocode 8: Design provisions for earthquake resistance structures - Part 1. Bruxelles, Belgium.

Constantin R., Beyer K., (2016) Behaviour of U-shaped RC walls under quasi-static cyclic diagonal loading, Engineering structures, Vol. 106, pp 36-52.

Dashti F., Dhakal R.P., Pampanin S. (2014) Simulation of outof-plane instability in rectangular RC structural walls. Sec- ond European Conference on Earthquake Engineering and Seismology. Istanbul, Turkey.

Dashti F., Dhakal R.P., Pampanin S. (2015) Development of out-of-plane instability in rectangular RC structural walls. 2015 NZSEE Conference.

Feenstra P. H., 1993, Computational Aspects of Biaxial Stress in Plain and Reinforced Concrete. PhD thesis, Delft University of Technology;

fib - International Federation for Structural Concrete: fib Model Code for Concrete Structures 2010. Ernst \& Sohn, Berlin, 2013;

Goodsir W. J. (1985) The design of coupled frame-wall structures for seismic actions. University of Canterbury, Christchurch, New Zealand.

Guidelines for Non-linear Finite Element Analyses of Concrete Structures (2012). Rijkswaterstaat Technisch Document RTD:1016:2012, Rijkswaterstaat Centre for Infrastructure, Utrecht, 2012.

Mander, J., Priestley, M., and Park, R. (1988). "Theoretical Stress-Strain Model for Confined Concrete." J. Struct. Eng., 10.1061/(ASCE)0733-9445(1988)114:8(1804), 1804-1826;

Manie J. (2015) DIANA User's manual, Release 10, TNO DIANA;

Fragiadakis M. , Pinho R. , Antoniou S. (2007) Modelling Inelastic Buckling of Reinforcing Bars under Earthquake Loading. ECCOMAS Thematic Conference on Computational Methods in Structural Dynamics and Earthquake Engineering. Rethymno, Crete, Greece, 13-16 June 2007.

Monti G. and Nuti C. (1992) Nonlinear cyclic behaviour of reinforcing bars including buckling. J. Struct. Eng., ASCE 118,12 (1992), 3268-3284.

Nakamura H., Higai T. (2001) Compressive Fracture Energy and Fracture Zone Length of Concrete, Benson P. Shing, J. Str. Eng. ASCE, 2001, pp. 471-487.

Oesterle, R. (1979) Earthquake Resistant Structural Walls: Tests of Isolated Walls: Phase II, Construction Technology Laboratories, Portland Cement Association.

Paulay T., Priestley M.J.N. (1993) Stability of ductile structural walls. ACI Structural journal 90:385-392.

Rosso A., Almeida J.P., Beyer K. (2015) Stability of thin reinforced concrete walls under cyclic loads: state-of-art and new experimental findings. Bull Earth Eng 2015 [published online]

Thiele K. , Dazio A. , Bachmann H., (2001) Bewehrungsstahl unter zyklischer Beanspruchung. Institut für Baustatik und Konstruktion Eidgenössische Technische Hochschule Zürich. Mai 2001.

Thomsen IV, J.H. \& Wallace, J.W. (2004) Displacement-based design of slender reinforced concrete structural wallsexperimental verification. Journal of structural engineering, 130(4): 618-630.

Vallenas J.M., Bertero, V.V., Popov E.P. (1979) Hysteretic behaviour of reinforced concrete structural walls. Report no. UCB/EERC-79/20, Earthquake Engineering Research Center, University of California, Berkeley.

Vecchio F. J. and Collins M. P. (1993) Compression response of cracked reinforced concrete. J. Str. Eng., ASCE 119, 12 (1993), 3590-3610.

Wallace J. (2012) Behavior, design, and modeling of structural walls and coupling beams-Lessons from recent laboratory tests and earthquakes. International Journal of Concrete Structures and Materials, 6(1): 3-18. 